\title{
JOSEPH SCALIGER'S HISTORICAL CRITICISM OF THE NEW TESTAMENT
}

\author{
by
}

\author{
H.J. DE JONGE \\ Leiden
}

The study of the earliest Christian literature, including the writings collected in the New Testament, became a literary and historical discipline in the nineteenth century. The subject is concerned with the question: what did this author wish to say to his readers or his audience in this work or this passage? This unavoidably raises a number of other questions. Do we possess the original text of the work under study? Why did the author choose this particular genre? How is the work composed? Is it in fact by the author to whom it is attributed? What models, sources or traditions did the author use? What does the work reveal about the position and social environment of the author? To what situation did he wish to react? How reliable is his presentation of affairs, so far as he wished to give an historical account? The number of questions is legion.

It was only gradually that the study of early Christian literature became a philological, literary and historical discipline. Before the nineteenth century the exegesis of biblical writings had naturally had a permanent place at the universities since the middle ages. But that traditional exegesis had for long, and in some places until the present day, set itself the goal of extracting from the bible the arguments and foundations on which to erect a body of doctrine.

The transformation of the study of the bible from serving the cause of dogmatics to a literary and historical discipline was caused by changes in the intellectual climate of Europe as a whole. The decisive impulses were given by three intellectual movements: (1) humanism; (2) rationalism; and (3), at the end of the eighteenth century, the liberal-Protestant, apologetic reaction to the destructive criticism of the Deists. ${ }^{1}$ I shall confine myself here to humanism. We can regard Erasmus (1466-1536),

\footnotetext{
1 M.H. de Lang, "Literary and Historical Criticism as Apologetics. Brblical Scholarship at the End of the Eighteenth Century," Dutch Reverw of Church History 72 (1992) 149-165; eadem, De opkomst van de histonsche en lteraure krtzek in de synoptwsche beschouzerng 
Hugo Grotius (1583-1645) and J.J. Wettstein (1693-1754) as the most important humanistic exegetes of the New Testament.

Humanism's primary contribution to biblical study was the conviction that the biblical writings had to be studied in their original language: Hebrew, Aramaic, Greek. We also have humanism to thank for the recognition of the biblical writings as documents bound to a particular period of history. The writings included in the bible are now regarded as documents, each of which must be placed in a particular ancient cultural context, and which were addressed in the first place to readers who were contemporaries of their authors, and not directly to a public in all ages and places. The writings of the bible have come to be better understood than before, as historically situated and defined by their historical context. They must therefore be explained, in the first place, within the historical framework of the time in which they were composed, by comparison with contemporary ancient literature. Of course, the dogmatic exegesis of the bible has not been immediately or universally superseded by historical exegesis since the seventeenth century. For some time historical exegesis remained an alternative practised by a few, chiefly philologists. But during the nineteenth century and in the twentieth century the historical approach to the bible has established its position, largely at the expense of the dogmatic and actualising approach.

What I wish to point out here is that the new methods which humanism brought to the study of the bible also led to the appearance of a modest form of historical criticism. The comparison of the biblical writings with contemporary literature which the humanists encouraged, resulted in the first attempts at a historical criticism of the contents of the bible. Naturally, the bible had posed historical problems for earlier ages as well. But exegetes had always got round these problems by harmonising explanations. The humanists, on the other hand, were fully aware, thanks to their extensive scholarship, that these harmonising explanations were no longer tenable. Many of the humanists possessed a good knowledge of Semitic languages such as Aramaic and Hebrew, and some of them also knew Arabic. Such knowledge gave them the confidence to form independent critical opinions. The improved knowledge of chronology also made a significant contribution to the rise of criticism. In this article I wish to show how the various factors could come together in the rudimentary beginnings of a historical-critical 
approach to the study of the New Testament, by examining several exegetical observations of the great Leiden humanist Joseph Scaliger. ${ }^{2}$

The philologist Joseph Scaliger (1540-1609), born at Agen in France, is known above all for his immensely learned and innovative magna opera in the field of chronology: De emendatione temporum $\left(1583^{1}, 1598^{2}, 1629^{3}\right)$ and Thesaurus temporum $\left(1606^{1}, 1658^{2}\right)$. He also produced critical editions of numerous classical authors. Four hundred years ago, in 1593, he came to Leiden at the invitation of the University. Here he became the master of numerous gifted students, among them Daniel Heinsius and Hugo Grotius. Scaliger taught them to see the New Testament as a body of writings that belonged to the historical and cultural world in which they had been written: the Hellenistic world of the first century A.D. The adjective "Hellenistic," now in current use, was coined by Heinsius from the noun used by Scaliger, "Hellenistae." Scaliger used this term to refer to those Jews who knew only Greek, and no Hebrew or Aramaic. For Heinsius, therefore, "Hellenistic" was the form of Greek used by such Jews: a language with a Greek vocabulary with Hebrew and Aramaic meanings. ${ }^{3}$

In his private lessons above all, to a much lesser extent in his printed works, and not at all in public teaching (from which he was exempted at Leiden), Scaliger discussed problems in the New Testament and passed judgements on them which can be considered historical criticism. I shall discuss several examples below. It will be apparent that the thinking of a humanist like Scaliger recognised historical problems presented by the texts, took them seriously and did not dismiss or trivialise them. It will also be clear that the humanist approach had its limitations: it was dominated by the typically humanist question, "is what is here the original text or not? Is it authentic or a later interpolation, that is a falsification?" The judgment of the "genuineness" of a work, passage or word, was one of the main tasks of the critic in the humanist programme. ${ }^{4}$ The result was that Scaliger dismissed as

${ }^{2}$ On Scaliger, see the magisterial intellectual biography by A. Grafton, Joseph Scalgger. A Study in the History of Classical Scholarship, I-II (Oxford: Clarendon Press, 1983-1993). For further literature on Scaliger, see A. Grafton and $\mathrm{H}_{\mathrm{J}} \mathrm{J}$. de Jonge, "Joseph Scaliger. A Bibliography 1850-1993," second edition, in R. Smitskamp, The Scalger Collection. Smtskamp Orental Antrquarum Catalogue No. 595 (Leiden: Smitskamp Oriental Antiquarium, 1993), i-xxx.

${ }^{3}$ H.J. de Jonge, "The Study of the New Testament," in Th.H. Lunsingh Scheurleer and G.H.M. Posthumus Meyjes (eds.), Lenden Unversity in the Seventeenth Century. An Exchange of Leaming (Leiden: Brill, 1975) 64-109, at pp. 83-84.

${ }^{4}$ See the article on "Critice" in P. des Maizeaux (ed.), Prma Scalygerana (Amsterdam: Covens \& Mortier, 1740) 62-63 According to Scaliger, the critic's task is "depravata 
inauthentic passages which he regarded as historically problematic because of their contents, that is he thought they were later interpolations. "Il y a plus de 50 additions ou mutations au Nouveau Testament et aux Evangiles." In view of the sensitivity of the subject Scaliger was afraid to discuss the matter in public: "C'est chose estrange, je n'ose la dire. Si c'estoit un auteur profane j'en parlerois autrement." Here historical criticism is expressing itself in the form of textual criticism. We see both the strength and the limitations (caused by a certain compulsiveness in the questions which humanism asked) of the humanistic approach to the New Testament.

\section{The duration of Jesus' public activity}

Scaliger held the view that John was the only one of the four evangelists to pay attention to the chronology of Jesus' public career. ${ }^{6}$ John refers, according to Scaliger, to four Passovers in which Jesus is supposed to have taken part during his public ministry: $2: 13 ; 5: 1 ; 6: 4$ and 11:55. Jesus' activity would therefore have lasted three years, according to John. But on chronological grounds Scaliger believed that Jesus was active in public for four years and not three, for his baptism occurred in the fifteenth year of Tiberius (Lk. 3:1). But according to John his death took place in a year in which the first full day of Passover, that is 15 Nisan, fell on a Saturday (John 19:14). That was the case not in the eighteenth but in the nineteenth year of Tiberius.?

emendare, falso attributa suis auctoribus asserere ac vindicare, omne genus poetarum, oratorum et philosophorum recensere atque excutere [i.e., 'to examine and investigate...'], nam critici erant veluti censores librorum." The Prma Scalgerana are a collection of excerpts from Scaliger's letters and fragments from private conversations with him, compiled before 1593 by a personal friend, the French medical doctor Françoss Vertunien (died 1609).

${ }^{5}$ P. des Maizeaux (ed.), Secunda Scalygerana (Amsterdam: Covens \& Mortier, 1740) 398-399. The Secunda Scalggerana are short notes in which Jean and Nicolas de Vassan, students of Scaliger at Leiden from 1603 tot 1606, tried to record what they had heard Scaliger say during their private sessions with him. Scaliger's utterances were later arranged in alphabetical order according to subjects. The authenticity of these sayings of Scaliger is beyond doubt, but allowance must be made for slight inaccuracies in their wording due to the possible misunderstanding or deficient recollection of Scaliger's words on the part of the brothers Vassan, or to the way they summarized and edited his teaching.

${ }^{6}$ Secunda Scalgerana, s.v. "Pascha," 491: "... solus Johannes narrat tempora."

7 This is Scalger's brief and simple assertion in the Scalgerana Secunda. It is based, however, on detailed and complicated chronological calculations which Scaliger presented in his De emendatone temporum and in his Thesaurus temponum, and for which see M.H. de Lang, De opkomst, 79-82. 
John's account of events therefore omits a year. Scaliger felt that it could best be inserted between the end of John 5 and the beginning of John 6. This year included everything related by Matthew in chapters 4 to 14 .

In this case Scaliger criticises, albeit in mild terms, the chronology of the fourth gospel, the only gospel, in his opinion, that had any chronological structure at all. He also offers a solution, but is prepared to abandon it if necessary: "Let everyone investigate whether there is a better solution: I shall be glad to accept it."

This criticism is based on Scaliger's highly specialised knowledge of technical chronology, and on his optimistic confidence in the accuracy of the results of that science. This confidence is no longer shared.

Scaliger also published this view of the chronology of Jesus' life, in detail, in his De emendatione temporum and in his Thesaurus. There had been discussion of the duration of Jesus' public career within the Church since Julianus Africanus (third century) and Eusebius: the subject was not taboo. The humanist and cartographer Gerardus Mercator, who had Reformation leanings, also fixed the duration at four years, though on quite different grounds from those adduced by Scaliger. ${ }^{9}$

\section{Mt. 1:2-17 and Lk. 3:23-38: the genealogies of Jesus}

Two of the gospels, Matthew and Luke, offer a genealogy of Jesus, but they differ widely from each other. Only for the generations from Abraham to David are they in reasonable agreement. But for nearly one thousand years between David and Jesus' father Joseph, the agreement is virtually non-existent. In Matthew, Jesus' descent runs through David's son Solomon, and in Luke through David's son Nathan. Yet both reach Joseph through the male line, though Matthew takes 25 generations and Luke 40.

Scaliger found these differences an insoluble problem: "C'est une grande difficulté, ce qui est dit en Saint Luc et en Saint Matthieu. Je n'en sçay que dire."10 That is all that Scaliger says of this matter, but his suspicion is clear: something is wrong with the lists.

The reason for Scaliger's mistrust is his awareness of the differences

8 Secunda Scalggerana, 491. "Omnes dispiciant, si quid melius; accipiam." Cf. p. I78: "J'ay montré où l'on pourroit prendre la cinquième [i.e., the fifth Passover in the gospel of John, which according to Scaliger could be placed between ch. 5 and ch. 6], je ne l'asseure pas. Qui trouvera mieux cherche, à grande peine."

${ }^{9}$ M.H. de Lang, De opkomst, 67-77.

10 Secunda Scalggerana, 340. 
between the two evangelists. He does not attempt, as so many had done since the early church and were still to do, to reconcile the lists with each other by explaining away their difficulties. He acknowledges the difference and can only see how one genealogy casts doubt on the other. In similar cases Scaliger, as will appear, regarded the passage which aroused his suspicion as a later Christian interpolation. He must have held the same view of one or other of the two genealogies of Jesus, perhaps of both. At least one genealogy, perhaps both of them, must have seemed to him without foundation.

\section{Mt. 2:16-18: the slaughter of the innocents at Bethlehem}

The gospel of Matthew relates that Herod the Great, king of Palestine from 37 to 4 B.C., had all the boys aged two or younger in Bethlehem put to death shortly after the birth of Jesus (Mt. 2:16). The evangelist adds that in this way a prophecy of Jeremiah (31:15) was fulfilled.

Scaliger felt that it was suspicious that the Jewish historian Flavius Josephus, who wrote a very detailed history of the Jews in the first century before and after Christ, said not a word of the massacre of the children, although it was an appalling atrocity and would not have been out of place in his account of the cruelties of Herod. "Why should Josephus have failed to mention this dreadful deed? Scaliger felt that the tale was unhistorical and a later addition to the text of the gospel.

In this case Scaliger's criticism is based on comparison of Matthew with a non-biblical author. He considers the latter, Josephus, to be above suspicion, and Matthew as suspect, for a reason which he repeats several times. Christians had an interest in claiming that the events of Jesus' life represented the fulfilment of Old Testament prophecies: this presentation guaranteed that Jesus was truly the saviour promised and sent by God. But according to Scaliger reports of the fulfilment of such Old Testament prophecies were added to the original text of the bible by later Christians. He thought that such "citationes prophetarum, quae passim in evangelistis habentur" could only alienate the Jews from Christ; but Christ's kingdom is not furthered by lies (mendacia). ${ }^{12}$ The

II Secunda Scaligerana, 399 "Il [1 e, Josephus] ne fait aucune mention de teknotona d'Herode, qui estoit une insigne cruaute" Scaliger followed this comment immedrately with the statement, already quoted above, "Il y a plus de 50 additions ou mutations au Nouveau Testament et aux Evangles "Scaliger's assessment of Josephus' silence on the slaughter of the mnocents is now endorsed by, e g, Steve Mason, Josephus and the New Testament (Peabody MA Hendrickson, 1992) and R H Gundry, Matthew A Commentary on his Literary and Theological Art (Grand Rapids Eerdmans, 1982) 37

12 Notae quaedam Ios Scalgger in Novum Testamentum quas Francusco Vertunaano alud agens 
reports in which the evangelists wished to make it appear that Old Testament prophecies had been fulfilled, were thus reduced to the status of mendacia. This criticism, also directed against the account of the slaughter of the innocents, had already been voiced by the Manichean Faustus of Milevis (late fourth century), against whom Augustine had written his Contra Faustum Manichaeum (c. 400). It has been revived in the sixteenth century in the circles around the Anabaptist Tiziano in the Rhaetian Republic. ${ }^{13}$

Naturally, Scaliger did not state his rejection of the historicity of the massacre of the innocents in public. He could only do so in his private teaching, yet he did point out in writing that it was amazing (mirum) that Josephus had been silent about the murder, ${ }^{14}$ although he had gone into great detail on the other bestial crimes of Herod. But Scaliger could not go further than this in print.

This case shows us how the reliability of the gospels could come to be criticised as a result of comparison with a non-biblical work.

\section{Mt. 2:23b: Jesus sent to Nazareth because the prophets had said that he would be called a Nasorean}

Matthew relates that after the flight to Egypt, Jesus' parents returned and settled in Nazareth "to fulfil the words spoken through the prophets: 'He shall be called a Nasorean'." According to Scaliger, by Nasorean, Matthew alludes to what is elsewhere usually called a Nazarite or Nazirite, a person who dedicated himself for a longer or shorter period to the service of Yahweh by observing particular rituals and ascetic customs.

As we would expect, Scaliger points out that the sentence "to fulfil the words spoken through the prophets: He shall be called a Nasorean," is an interpolation. It is a Christian addition to the text of Matthew, and a foolish one; "additiones sunt veterum christianorum ineptae." 15 For the Aramaic words for Nazarite (dedicated person) and Nasorean or Nazarene (inhabitant of Nazareth) are very different. No one with

communicavit, MS. Paris, Bibl. Nat., Gollection Dupuy 395, fol. 19ro.-22ro: "citationes prophetarum quae passim in evangelistis habentur (...), cum falsae sint, Iudaeos a Christo alienare possunt; neque vero provehitur regnum Christi mendaciis."

${ }^{13}$ M.H. de Lang, De opkomst, 46-47.

${ }_{14}$ Scaliger, Thesaurus tempormm (Amsterdam: Janssonius, 16582), Animadversiones in Chronologica Eusebii, col. 176b: "mirum est tam beluinae crudelitatis exemplum a Josepho praeteritum esse, qui tanta diligentia reliqua saevitiae Herodianae facinora persequitur."

${ }^{15}$ MS. Paris, Collection Dupuy 395 (cf. n. 12 above), fol. 19ro. 
the slightest knowledge of Aramaic could have written the disputed sentence. The passage cannot therefore be by Matthew. Nor could anyone in the time of Jesus have said that his removal to Nazareth was the fulfilment of a prophecy. There is no historical basis for the passage. Once again, it is a Christian interpolation.

Scaliger's criticism here is based on his knowledge of Aramaic. $\mathrm{He}$ supposes that Matthew had spoken Aramaic and could not have confused Nasorean and Nazarite. Scaliger must have thought that the Greek Gospel of Matthew was a translation from Aramaic. The translation or later transmission of the text had entailed interpolations, Scaliger thought. His critical attitude was reinforced by his suspicion of the reports of the fulfilment of prophecies ${ }^{16}$ in general. On another occasion Scaliger remarked that the book of the prophet referred to had not been preserved. ${ }^{17}$ In fact it is not clear to which Old Testament passage Mt. 2:23 refers, but Scaliger does not exclude the possibility that a book had existed to which the interpolator could have referred. Nevertheless the association of Nasorean with Nazareth was a "howler" for which Scaliger felt the evangelist could not be held responsible. Nowadays a different opinion is held.

In the background to all his learning and critical acumen, it is clear that Scaliger, like others, assumed that the original gospels could not have contained any errors. He was after all a convinced and orthodox Calvinist, who took the infallibility of the Scriptures as axiomatic. If he found errors in them, they must be later interpolations, falsifications introduced during the process of textual transmission.

\section{Mt. 14:3-6, Mk. 6:14-29: the former husband of Herodias}

Mk. 6:17 and Mt. 14:3 form the beginning of the account of the death of John the Baptist. Here the evangelists introduce Herodias, the wife of Herod Antipas, tetrarch of Galilee and Perea from 4 B.C. to 39 A.D. According to the evangelists, before she married Herod Antipas,

\footnotetext{
16 The so-called "fulfilment-quotations," also called "reflection-quotations;" e.g., Mt. $1: 22 ; 2: 15,17,23 ; 4: 14 ; 8: 17 ; 13: 35 ; 21: 4 ; 26: 56 ; 27: 9$.

17 Secunda Scalggerana, 472: "Nazaretanus vocabitur,' Math. 2:23, dictum est apud Prophetam qui nunc non extat, qualia et multa citat Paulus, ut illud 'melius dare quam accipere' non extat. Et alia citat Paulus, quae in Veteri Testamento non extant. Judas citat Prophetiam Enoch, quam ipsam habet Graece scriptam Scaliger, ut alia eiusdem autoris falsa et supposita fragmenta. Remisit [sc. Scaliger] nos [the brothers Vassan] ad Eusebium [i.e., the Thesaurus temporum, in which Scaliger edited for the first time long fragments of I Enoch from Syncellus]."
} 
Herodias had been "the wife of Philip his brother." But Flavius Josephus names as her former husband not Philip but Herod, a half brother of Herod Antipas. ${ }^{18}$

Scaliger considered the discrepancy between the evangelists and Josephus nothing less than a "chose terrible." He remarks that Josephus was a very reliable, scrupulous and well informed historian, who in this case had no reason whatever not to tell the truth. Josephus, after all, relied on the Acta Herodis as his archival sources. ${ }^{19}$

In this last detail Scaliger is mistaken. It is true that in his Antrqutates $\mathrm{XV}$, vi, 3, 174, Josephus says that his information was taken from the memorrs of king Herod, but he was referring to Herod the Great and not to his son Herod Antipas.

None the less, Scaliger had good grounds for his suspicion that Mark and Matthew had been mistaken as to the name of Herodias' first husband. In fact Josephus is a better informant on this point than the evangelists - i.e., really Mark alone, as Matthew goes back to him. Mark's error is to be explained by a confusion of Herodias' husband with her son in law, who was indeed called Philip. Luke corrected the error in Mark by simply omitting the name.

Scaliger's criticism, in this case not unfounded, is once again the result of a comparison between the gospels and a non-biblical source. In this case he took the view that the latter could claim greater credibility than the evangelists.

The example is a good illustration of Scaliger's belief that it was necessary to use sources outside the bible to obtain an accurate knowledge of ancient times, including biblical history. Those who "volunt omnia ex Bibliis haurire, nec legunt bonos autores," ${ }^{20}$ fall irrevocably into historical errors. Moreover, for an accurate historical interpretation of the bible, non-biblical authors, that is profane authors of antiquity and Jewish writers, are completely indispensable. "Lisez les bons auteurs, illa sunt necessaria ad Biblia." ${ }^{21}$ For Scaliger this plea is necessary, because the Fathers of the Church had made many mistakes through lack of linguistic knowledge and literary erudition. The

\footnotetext{
${ }^{18}$ Josephus, Antrquttates, XVIII, v, 1, 109

19 Secunda Scalggerana, 398-399 "Cela d'Herodias femme d'Herode, qui est autrement dans Josephe, est une chose terrible, car qui l'auroit induit a mentrr Les Chrestiens anciens ont beaucoup adjouste au Nouveau Testament Ils peuvent aussi avoir change celui-la Josephe est un auteur tres veritable en son historre, et plus veritable que pas un auteur, et tres fidelle Il dit l'avoir ex actrs Herodıs"

${ }^{20}$ Secunda Scalgerana, 491

${ }^{21}$ Secunda Scalggerana, 453
} 
ignorance of the Fathers is a recurrent theme in Scaliger: "La grande ignorance de ces pères depuis 1300 ou 1400 ans: les Jésuites voudroient que nous demeurassions en ces tenèbres-là." "22 "Tam multa nugacia habent Patres! Habent praeclara quidem, sed cum judicio sunt legenda. ${ }^{\prime 23}$ Scaliger's argument is that the interpreter of the bible should make himself familiar with the world in which the biblical writings were composed by reading contemporary pagan and Jewish literature. $\mathrm{He}$ is not dispensed from this reading by a knowledge of the Fathers.

Finally, we observe once more that Scaliger did not think it possible that the evangelists themselves had committed the error of calling one of the Herods Philup. The original text of the evangelists cannot have included the mistake; consequently it must have been added later, as Christians transmitted, expanded, and altered the text.

\section{Fohn 9:7: the pool of Siloam, "Sent"}

In the account of the healing of the blind man Jesus says to the patient: "Go and wash in the pool of Siloam." The evangelist adds the explanation: "the name means 'sent" (John 9:7)

Siloam is the Greek version of the Hebrew proper name Shiloah (Isarah 8:6, Nehemiah 3:15). The explanation "sent" rightly assumes that Shiloah is derived from the Hebrew verb shalah, "to send," but the suggestion that the Hebrew name was a covert allusion to the person of Jesus, the sent one par excellence, is of course due to the evangelist and to the Christian tradition on which he drew. In fact Shiloah means "way" or "counduit," in this case the aqueduct by which water was led from a well.

In an oral commentary on John 9:724 Scaliger explains correctly that Shiloah was an outlet where "a stream, an arm, flows out of a greater water, as the Rhone flows from Lake Geneva": "lors que fluentum aliquid, un bras, sort d'une grande eau, ut Rhodanus ex lacu."

The pool referred to in John 9:6 was the reservoir in Jerusalem in

22 Secunda Scalgerana, 496-497

23 Secunda Scalygerana, 179

24 Secunda Scalgerana, 574, s v "Siloe" "quı vaut autant a dire que 'envoye' est addıto veterum chnstianorum, qu omnia quae putabant christianismo conducere, Biblis interseruerunt Male Car ls le prennent pour le nom propre de Christ, au lieu qu'icy Siloe signifie autant que Gichon, qui est comme une escluse, lors que fluentum aliquod, un bras, sort d'une grande eau, ut Rhodanus ex lacu, tellement que erat piscina, et ex illa piscina aqua defluens Christus in Veterı Testamento propro nomine vocabatur Silo, adjectivum vero est Messias" 
which water was collected from the well of Gihon or Gison, which lay outside the city. The water was brought into the city via an aqueduct and tunnel (Shiloah). The conduit between the well of Gihon, outside the city, and the basin within the city was called Shiloah, in Greek Siloam. The basin was therefore called "the pool of Siloam," after the conduit.

Scaliger shows himself well aware of these realia and of the linguistic background of the name Shiloah/Siloam. He considers the name Shiloah to be such a technical term for the aqueduct by which the water was led away from Gihon, that he has no need whatever for the allegorical explanation that applied the name to Jesus as the "sent one." If that explanation were correct, the basin would have borne a name which contained a hidden allusion to Jesus for centuries before his coming.

Scaliger thus rejects, on linguistic and historical grounds, the genuineness of the phrase "the name means "sent." In his view it was a later Christian addition to the text of the gospel. The passage had been inserted by Christians who believed they could see in the name of the pool an allusion to the person of Christ. "It is an addition of the early Christians, who included in the bible everything which they thought could support Christianity."

Historically and linguistically, according to Scaliger, the explanation in John 9:7 could not be correct. For that reason the explanation could not be the work of the evangelist. And this meant that the passage was a later interpolation. Once again, it is assumed that the original text of the gospels could not have contained any historical inaccuracies. That the evangelist himself should have wished to attach an allegorical explanation to the name of Siloam, is a possibility for which there was no room in Scaliger's humanistic practice of history. For the historical problem which he believed he detected, textual criticism again had to offer the solution.

\section{Mark 15:25 and John 19:14: the hour of Jesus' crucifixion}

According to Mark Jesus was crucified at the third hour of the day (9 a.m.), but according to John some time after the sixth hour (12 noon).

Scaliger makes no attempt to explain away the difference of three hours. On this point, he admits, the gospels are contradictory. But this contradiction forms a great problem for the historian and especially for the chronologist. "It is a great difficulty. It is an error as a result of the corruption of the manuscripts. The corruption dates from long ago, 
for Augustine is at pains to find a solution..$^{25}$ The corruption was promoted because copyists used only one manuscript as their model. And the monks stuffed in all kinds of things, depending on their ignorance. ${ }^{226}$

Scaliger means that if the copyists had checked their copy against another manuscript, not the exemplar they had used as their model, they would have been able to notice their copying errors and correct them. It should be remarked in passing that in reality many copyists of New Testament texts did use more than one manuscript as their model. The resulting contamination in the textual tradition of the New Testament is one of the greatest problems in modern textual criticism of the New Testament. ${ }^{27}$

The historical problem presented by the contradiction between the gospels, was in Scaliger's view the result of an error in the manuscript tradition of one of the two gospels. Again, textual criticism was invoked to offer a solution to an historical problem.

Scaliger appears to proceed on the assumption that the gospels in their original form must have given uniform accounts of the events which they related, for the history behind them was a single one. The gospels must have given an exact and reliable account of that single history. Consequently they must have agreed with one another in the historical information they provided. Scaliger was not yet able to grasp that exact information was not available about everything from the beginning, and that the gospels do not attempt to give an exact and consistent chronology.

The humanist historian and chronologist wishes to save the reliability of the gospels by imputing the evidence against it to flaws in the transmission of the texts. Here too, historical criticism seeks a solution in textual criticism.

8. Mt. 28:1, Mk. 16:2, Lk. 24:1, John 20:1: at what tome dud the women come to the tomb of Jesus?

The gospels do not agree in their accounts of the time at which Mary Magdalene and the other women came to his tomb on the day of Jesus' resurrection:

${ }^{25}$ Augustune, De consensu evangelistarum, III, xul, 41-50

2.6 Secunda Scalgerana, s v "hora," 382

${ }^{27}$ See, e g, Gerd Mink, "Eme umfassende Genealogie der neutestamentlichen Uberleferung," NTS 39 (1993) 481-499, e g , p 488 "Der stark kontammierte Charakter der neutestamentlichen Überlieferung ermoglicht offenbar ene weitgehende Strukturierung des Materials durch solche Gruppen nicht" 
Mt. 28:1: "about daybreak"

Mk. 16:2: "very early . . . just after sunrise"

Lk. 24:1: "on the Sunday morning very early"

John 20:1: "early on the Sunday morning while it was still dark."

The first three statements do not differ too widely in their chronology, but John clearly deviates from the other three evangelists.

According to Scaliger the difference between the evangelists was to be blamed on a mistake made by a copyist. "That according to one evangelist [sc. Mark] the women came to the tomb very early, at sunrise, is an error and a corruption for which a copyist is responsible. I do not know what I must say about it. Ambrose, Augustine and Chrysostom racked their brains over it in vain (...) It is evidently the fault of a copyist. The manuscripts could be corrupted, just as they can now. What is written on paper has always been liable to corruption."28

By now we are familiar with the reasoning which Scaliger followed. Originally the evangelists must have agreed with one another, because they could not have contained any errors. In cases in which they contradict one another, the discrepancy must have originated through a flaw in the transmission of the text of one or more gospels. Historical criticism seeks a way out in textual criticism.

\section{Acts 13:8: Elymas, "the sorcerer"}

In Cyprus Paul met a Jewish "sorcerer" called Elymas. Acts 13:8 speaks of him as follows: "Elymas the sorcerer (so his name may be translated)."

According to Scaliger the whole passage "the sorcerer (so his name may be translated)," is a later addition..$^{29}$ It does not belong to the original text of Acts. The explanation given in parenthesis is based on the fact that in Arabic a word 'alim occurs, which means "one who knows, a clairvoyant, a sorcerer." But, says Scaliger, Arabic was not yet spoken on Cyprus at the time of Paul, and the explanation is therefore an anachronism.

In fact, according to Scaliger, "Elymas" (to be accented as perispomenon and not as paroxytone) is a popular abbreviated form of the Greek name Elymoteros, similar to Olympas as an abbreviation for

${ }^{28}$ Secunda Scalgerana, s v. "error," 312-313 of Eils.

${ }^{29}$ Secunda Scalgerana, s v "Elymas," 303-304.

Ad Mariaum PE 22 
Olympiodorus. This is a rather unsatisfactory solution, since the name Elymoteros is not known from any other source. But in any case, Scaliger felt that the derivation of the name "Elymas" from an Arabic word was to be rejected.

In this case Scaliger's criticism is directed primarily against the assumption that Arabic was spoken on Cyprus in the first century A.D. In his view, such an assumption was unjustified. Hence, the explanation based on it in the phrase "the sorcerer (so the name may be translated)" has no historical foundation in the first century A.D. The first century author of Acts, Luke, cannot have committed such an historical error, in Scaliger's opinion. The sentence is therefore not by Luke, but by an interpolator: "Cette exposition d'Elymas, 'c'est à dire Magus,' est addita in textu, qualia multa; non est genuina." 30

This verdict comes down to saying that the information contained in the disputed phrase may well be linguistically correct in principle, but cannot refer to the first century Elymas in Cyprus. Consequently the phrase is unacceptable historically and eo ipso from the text-critical point of view as well. Scaliger's objection is presented as a historical criticism but is naively elaborated into the text-critical verdict: delete. Thus he tries to save the credibility of Acts in its assumed earlier and shorter form. In the background is the idea that the biblical text cannot originally have contained any historical error.

\section{Josephus, Antiquitates XVIII, ni, 3, 63-64: the Testmonium Flavnanum} about Jesus

To the previous nine examples of criticism of passages in the New Testament I now add a case of criticism of Josephus. For Scaliger this was a question of the same order. It concerns the so called Testimonium Flavianum, the passage in Josephus' Antrquttates, XVIII, iii, 3, 63-64, in which Jesus is referred to as a worker of miracles who won many followers but was condemned to be crucified by Pilate. "And this was the Messiah," says the passage about Jesus.

In 1965 Louis H. Feldman wrote of this passage: "Ever since Scaliger in the sixteenth century ${ }^{31}$ first suspected the authenticity of the so-called Testimonium Flavianum, an enormous literature (for which see espe-

\footnotetext{
30 Secunda Scaligerana, tbid, 304

${ }^{31}$ The sayngs of Scaliger transmitted in the Secunda Scalggerana date from the years 1603-1606.
} 
cially Schürer and Eisler) ${ }^{32}$ has developed concerning it." ${ }^{933}$ Feldman does not cite the words in which Scaliger denied the authenticity of the Testimonium Flavianum. Here I shall cite two passages from the Secunda Scaligerana.

First from a passage about Josephus:

On lui [z.e., Josephus] a adjousté le traitté de Jésus-Christ. Quel danger y eust il eu que Josephe n'eust point fait mention de Jésus-Christ? Ce sont des chrestiens qui y ont adjousté celà." ${ }^{\prime 34}$

And then from a passage on the corruption which ancient texts suffered in the course of their transmission:

La depravation a esté plus grande, parce qu'on n'a descrit que d'un exemplaire. Et les moines ont farcy beaucoup selon leur ignorance, comme dans Josephe, ainsi qu'Eusèbe le cite, tellement que la depravation est bien ancienne. ${ }^{35}$

Scaliger does not give explicit reasons for dismissing the Testimonium Flavianum as a Christian interpolation. But we can deduce them from his discussions of other specimens of Christian pseudepigraphic literature, such as the Christian Sibylline oracles. "Christians have judged the word of God to be so inefficacious that they doubted the kingdom of Christ could be furthered without lies." 36 "Early Christians thought that they could further the kingdom of God by lies and forged tales of miracles; they erred gravely in this." ${ }^{\prime 37}$ Scaliger regarded Christian pseudepigraphy as the misleading utterances of apologists. These texts had been invented by early Christians to call into being convincing witnesses to whom they could appeal in defence of their opinions against Jews and pagans. Scaliger believed the Testimonium Flavianum was one of these expressions of misleading early Christian apologetics. The

32 Feldman (see next n.) refers to E. Schurer, Geschuchte des judischen Volkes $2 m$ Zeitalter Jesu Chrst I (Leipzig: Hinrichs, 1901) 544-549, and R. Eisler, The Messiah Jesus (tr. by A.H. Krappe; London: Methuen, 1931) 36 sqq. See also "Appendix K. Selected Literature on the Testimonium Flavianum" in Feldman himself, 573-575, and E. Schurer, The History of the Jewrish People in the Age of Jesus Chrst (rev. and ed. by G. Vermes, e.a.) I (Edinburgh: Clark, 1973) 428-441: "Josephus on Jesus and James."

${ }^{33}$ Louis H. Feldman, Josephus, vol. IX, Jewrsh Antiqunties XVIII-XX (Loeb Classical Library 433; Cambridge MA: Harvard University Press/London: Heinemann, 1965) 49.

34 Secunda Scalggerana, s.v. "Josephe," 399.

35 Secunda Scaligerana, s.v. "Hora," 382-383.

${ }^{36}$ Scaliger to Isaac Casaubonus, Leiden, 30 October 1605, see his Ephstolae (Leiden: Elzevir, 1627) 303-304: "Adeo verbum Dei inefficax esse censuerunt [sc. Christiani], ut regnum Christi sine mendaciis promoveri posse diffiderent." Scaliger followed this remark with the complaint: "Atque utinam illi primi mentiri coepissent."

${ }^{37}$ Prma Scaligerana, s.v. "Mendaciis," 122: "Mendaciis et falsis miraculis putaverunt veteres se posse Regnum Dei provehere; in quo graviter errarunt." 
early Christians, he reasoned, would have seen the danger if Josephus, who wrote such a detailed history of the Jews in the time of Jesus, had passed over Jesus himself in silence. Such silence on the part of the Jews would have cast doubt on the reliability of the early Christian accounts of Jesus' career and death. To avoid this danger Christians had added the passage about Jesus in Josephus. But according to Scaliger, "quel danger y eust il eu que Josephe n'eust point fait mention de Jésus-Christ?"38

Scaliger was aware that the interpolation, in his theory, must date from before ca. 324 A.D., when Eusebius cited the Testimonium Flavianum in his Hzstona Ecclesiastica. ${ }^{39}$ For this to be the case, he had to date the emergence of monasticism, which he held responsible for the corruption, earlier than he was usually willing to do and than historical documentation allowed. Nevertheless: "Les moines ont farcy beaucoup selon leur ignorance, comme dans Josèphe, ainsi qu'Eusèbe le cite, tellement que la depravation est bien ancienne."40

It is striking that Scaliger passes his verdict on the Testimonium Flavianum as a Christian interpolation without being able to compare what he regarded as the corrupt text of Josephus with a purer, shorter text. There was and is no textual witness without the alleged interpolation. Here Scaliger let himself be guided solely by his opinion of the content of the passage in question. Clearly he did not consider it to be in agreement with what might be expected of Josephus. This is a literary-historical judgment, the tendency of which is: this content cannot be by Josephus. The conclusion is textual-critical in nature: the passage must be an interpolation.

\section{Conclusion}

The historical criticism which Scaliger formulated on the gospels and Acts was based on a variety of grounds:

1. comparison of the canonical writings with non-biblical sources, especially Josephus;

2. comparison of the gospels with one another;

3. knowledge of Semitic languages and of the history of their expansion;

4. knowledge of technical chronology;

\footnotetext{
38 Secunda Scaligerana, 399

${ }^{39}$ Eusebius, Hist Eccl I, 11, also in Dem Ev III, 5, 105

40 Secunda Scaligerana, s v "Hora," 382-383
} 
5. the assumption that the gospels and Acts must have been historically reliable at first, and could not have contradicted one another.

What gives Scaliger's criticism its force, is that he does not minimise or explain away the historical problem he recognises, but takes it entirely seriously. Its weakness is that he disqualifies historically unacceptable passages as corruptions in the textual transmission. But to judge this fault a weakness is to pass a verdict by modern criteria, by which Scaliger must not be measured.

However far Scaliger went in his criticism of the gospels, he remained fundamentally convinced that the history behind these documents could be known and reconstructed. For example, he felt justified in believing that Jesus had had a public career of four years. John offered a chronology of Jesus' activity which was essentially accurate, provided that another year was inserted somewhere in John's account, using material from the other gospels. On the whole, Scaliger was optimistic about the possibility of obtaining accurate historical knowledge of Jesus and of the church until the date of Paul's stay in Rome (62 A.D.). Not until the later seventeenth and eighteenth century was confidence in the historicity of the gospels to be transformed in some authors into systematic distrust; ${ }^{41}$ Scaliger had not reached that stage. He thought it necessary to use the data in the bible in conjunction with nonbiblical data, but he continued to believe that the history behind the gospels could be reconstructed. Scaliger was a critical historian, but very far from being a sceptic.

Yet there is an element of personal drama when one looks at Scaliger's reaction to the historical problems that the gospels posed for him. He believed that his knowledge of many languages and literatures and of chronology had made him more learned in history than anyone else in his time. But as he began to feel old age advancing ${ }^{42}$ he was repeatedly compelled to acknowledge that the history behind the sources was not at all clear. Scaliger regularly confesses his uncertainty. On the genealogies of Jesus: "C'est une grande difficulté, je n'en sçay que dire." On the question of the time at which Jesus was crucified: "C'est une difficulté grande." On the time at which the women came

${ }^{41}$ HJ. de Jonge, "The Loss of Fath in the Historicity of the Gospels: H.S Reimarus (ca. 1750) on John and the Synoptucs," in A. Denaux (ed.), John and the Synoplzcs (BETL 101; Leuven: University Press/Peeters, 1992) 409-422.

42. Secunda Scalgerana, 551 “... je deviens aagé, je ne dors que trois heures, je me couche à $\mathrm{dxx}$, je me resveille à une et demie et ne puis plus dormır depuis" (to be dated before 1606). 
to the tomb of Jesus: "Nescio quid dicam." On the wrong name of Herodias' husband in Matthew and Mark: "Est une chose terrible." And on the interpolations which he suspected in the gospels: "C'est une chose estrange." The disappointment and doubt are unmistakable. It seemed that the chief documents of his religion were not entirely reliable. It is pointless to remark that Scaliger asked too much of the gospels, expected of them what they would not and could not give: historicity. It is better to try to understand the uncertainty and fear by which Scaliger must have felt threatened.

According to a seventeenth century tradition Scaliger wrote a work "on the insoluble problems of the Scriptures," De insolubilibus Scmpturae, which he himself is said to have destroyed. ${ }^{43} \mathrm{I}$ do not know the truth of this story. But when one listens to the 65-year old Scaliger speaking of the gospels in Lerden, one will consider it possible both that Scaliger wrote such a book and that he ultimately preferred to destroy it.

\footnotetext{
${ }^{43}$ AJ van der Aa, Brographusch Woordenboek der Nederlanden, vol 17 (Haarlem, 1874) 175 "According to Guy Patin, Scaliger also composed a work de msolubulibus Scrnplurae and a geography of the Bible, both of which he destroyed" (my translation)
} 